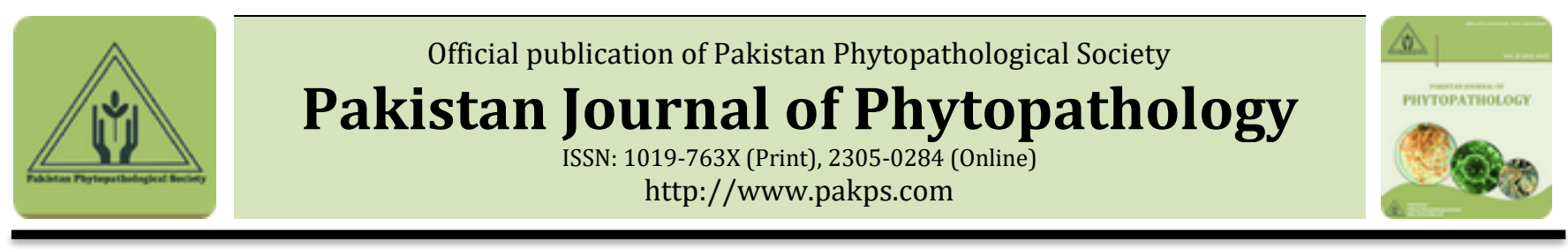

\title{
DISTRIBUTION AND VIRULENCE OF ROOT-KNOT NEMATODES ON SUMMER VEGETABLES IN SUDHNUTI DISTRICT OF AZAD JAMMU AND KASHMIR
}

\author{
${ }^{a}$ Muhammad Tariq-Khan, aAbu Daud Ahmad Khan, bMuhammad Saeed, aSyed Zanib Ali Gardazi, aBasharat \\ Mehmood, cMuhammad Ilyas, aRaees Ahmed \\ a Department of Plant Pathology, Faculty of Agriculture, University of Poonch Rawalakot, Pakistan \\ ${ }^{b}$ Wheat Research Institute, Sub-Station Sunny Bank Murree, Punjab, Pakistan \\ ${ }^{c}$ Department of Plant Breeding and Molecular Genetics, Faculty of Agriculture, University of Poonch Rawalakot, Pakistan
}

\begin{abstract}
A B S T R A C T
Root-knot nematodes (RKN) are root pathogens of important vegetable crops belong to genus Meloidogyne with worldwide distribution resulting in responsible for huge yield losses. Tropical species cause severe yield losses on vegetable crops in Azad Jammu and Kashmir. A detailed field survey was conducted in vegetable producing areas of the district Sudhnuti for the estimation of incidence and collection of the RKN targeting variety of vegetables. A total of 65 sites were visited during the survey, 47 sites found with 72 percent incidence and severity galling index range 2-8. Eggplant, tomato, cucumber, okra, beans, cucurbits, and chilies observed as the most frequently cultivated vegetables in the area. Host plants harboring RKN were enlisted along with non-host plants on positive sites. The altitude, longitude, latitude, and other related data of the surveyed sites were documented and a distribution map was prepared. The cucumber was found most frequently infested crop with 11 infested fields followed by okra and other cucurbits with 9 fields and tomato with least field infestation 07 fields. RKN was not infesting chilies crop in the area. The study elaborates a detailed comprehensive picture of incidence, prevalence and virulence potential of RKN in the Sudhnuti district, Azad Jammu and Kashmir, Pakistan on vegetable crops.
\end{abstract}

Keywords: Root-knot nematodes, Eggplant, Meloidogyne spp., Vegetables, Incidence

\section{INTRODUCTION}

Root-knot nematodes (RKN) belong to the genus Meloidogyne are major pathogens all around the world targeting quality and quantity in both tropical and temperate areas (Anwar and Mckenry, 2012; Sikora and Fernández, 2005) especially vegetables and their damage is more in tropical climate rather than temperate climate. The genus includes more than 100 described species (Wesemael et al., 2011). Among major species, M. arenaria, M. javanica, M. incognita are tropical while M. hapla, M. chitwoodi and M. enterolobii are temperate species. $M$. incognita and $M$. enterolobii are declared quarantine pests by several countries Submitted: May 12, 2020

Revised: July 15, 2020

Accepted for Publication: September 28, 2020

* Corresponding Author: Muhammad Tariq-Khan

Email: muhammadtariq@upr.edu.pk

(C) 2020 Pak. J. Phytopathol. All rights reserved. including the EU (Hussey and Janssen, 2002). In Pakistan, Root-knot nematodes (RKN) distributed in 76 percent soils of orchard and vegetable areas in Punjab. RKN (Meloidogyne spp.) distribution, incidence, and prevalence in some areas of Punjab has estimated 6$100 \%$ vegetable fields (Shahid et al., 2007); 85\% association with vegetable crops in Punjab (Anwar et al., 2007a); and estimated infestation level for tomato was 81\% (Khan et al., 2005). Potohar region of Punjab is comparatively cooler and rainfed, where cucurbits are infested by RKN, and $M$. incognita is predominant species with the presence on $79 \%$ surveyed fields followed by M. javanica on $19 \%$ sites and M. arenaria on $2 \%$ sites in several districts of the region (Kayani et al., 2013). In Malakand division, Northern KPK Province, $M$. incognita, M. javanica and $M$. arenaria are leading species on tomato crops with an incidence of $83 \%$ field infestation in Swat and 52\% in Malakand with varying population trend of either single species or 
combinations of various RKN species (Naz et al., 2012). Azad Jammu and Kashmir remained neglected regarding plant-parasitic nematode studies. Previously a little information has existed regarding the presence of rootknot nematode (Maqbool and Shahina, 2001) from Azad Kashmir. Studies on RKN distribution, the prevalence of root-knot nematodes, and host range was carried out in Muzaffarabad and Poonch divisions of the area (TariqKhan et al., 2017; Khan, 2018; Tariq-Khan et al., 2020) but deep details are needed to be bridged up. District Sudhnuti is located at Latitude $33^{\circ} 42^{\prime} 54^{\prime \prime} \mathrm{N}$, Longitude $73^{\circ} 41^{\prime} 9^{\prime \prime} \mathrm{E}$, altitude 1419 meters and has a hilly landscape in the Poonch division of AJK. Climate is warm and temperate, annual temperature ranges from 20$35^{\circ} \mathrm{C}$ in summer and $0-2^{\circ} \mathrm{C}$ in winter with average annual rainfall of $584 \mathrm{~mm}$. The objective of the study was to determine the distribution, incidence, prevalence, disease severity, identification of host range and nonhost plants of the root-knot nematodes among vegetables with recent climatic changes worldwide and especially in Azad Jammu and Kashmir, Pakistan.

\section{MATERIALS AND METHODS}

The vegetable fields were selected and observed for the presence of root-knot nematodes. Plants with reduced growth were selected and uprooted randomly to check for knots and galls. Infested roots were cut with a sharp cutter and packed in polythene bags. All positive and negative sampled sites were enlisted. Spade sampler was used for carefully sampling vegetables roots to avoid roots damage. Soil samples (500 gm. kg-1) were taken from the infested sites. The moisture level of soil samples was properly maintained and samples were kept in dark. Samples were then packed safely in wooden boxes for transportation. Root and soil samples were stored at $4{ }^{\circ} \mathrm{C}$. Infested roots were cold dried and preserved at $-20{ }^{\circ} \mathrm{C}$. Root-knot nematode (RKN) incidence was estimated by the percentage formula (Barker et al., 1998).

$$
\text { Disease incidence } \%=\frac{\text { No. of diseased plants }}{\text { Total observed plants }} \times 100
$$

The severity of root-knot nematode infestation was estimated by visual comparison of the diseased roots according to Bridge (1980) scale. Isolation of RKN from soil samples was done by taking $100 \mathrm{gm}$ of composite samples using a modified Baermann funnel technique and tray method. The samples were kept for 72 hours until the nematodes hatched out from the soil samples were moved into the water followed by harvesting of nematodes and then nematodes counting under a stereomicroscope. This process had given us complete nematode fauna of the soil samples. For the isolation from root samples, infested roots were separated, washed under tap water, blended and then females were picked for identification. Female's perennial patterns were prepared by trimming with needles under stereomicroscope put in the glycine fine drop on slides covered with a coverslip for observation under a compound microscope and compared to the literature for identification. Perineal patterns of 20 females per sample were identified for special status. Females were mechanically excised from the roots with the help of needles under a stereomicroscope and egg masses were separated further used as a purified culture. Single egg masses were collected from the infested root samples with the help of a sharp needle and treated with chlorox solution for the disintegration of gelatinous layer and release of the eggs in the glass Petri dish. The eggs were put at room temperature for hatching and then hatched second-stage juveniles (J2) were transferred to the susceptible host plant (Moneymaker or eggplant) for establishment and multiplication. The inoculated plants were kept at $25 \pm 2{ }^{\circ} \mathrm{C}$ in a light-dark interval of $16: 8$ hours for the propagation and buildup of nematode inoculum (Benson and Barker, 1985).

\section{RESULTS}

Distribution of root-knot nematodes in district Sudhnuti, Azad Kashmir: Our survey studies revealed that in Sudhnuti vegetables are widely cultivated in the district which is a high frequency of cultivation when compared to other districts of the division (Khan, 2018). The most frequently cultivated vegetable crops in the study area were cucumber, okra, cucurbits, tomato, beans, and eggplant. Overall, 65 sites were surveyed during this course of study, to determine the occurrence, incidence, and virulence of root-knot nematodes were estimated and summarized (Table 1, 2, 3). Survey site details for the presence or absence of RKN to determine the nematode free fields, disease severity on the infested roots, host range, a non-host crop of infested fields were recorded and summarized (Table 2). The distribution pattern was prepared and given as a distribution map (Figure 1). The total incidence in the district Sudhnuti was recorded as 72.30 percent from 65 surveyed sites (Table 1). The host range of root-knot nematodes (RKN) was found with variation representing their host preference among available host crops. The frequency of 
cultivated vegetables from district Sudhnoti were summarized (Table 1). Cucurbits including cucumber are the most frequently cultivated vegetables on 75 locations and eggplant is least with a presence on six locations. RKN infestation on cucurbits at 15 sites was recorded and disease severity was high on $50 \%$ of infested sites showing the disease scoring 5 or more according to bridge and Page standard scale (Bridge, 1980) which is threatening indicator for the crop (Table $2,3)$. The results showed that the RKN pathogen from Sudhnuti prefers to infect cucumber and okra as host. The same pattern of virulence was observed in the region (Tariq-Khan et al., 2020; Tariq-Khan et al., 2017). It also shows that the environment of Sudhnuti is favoring the distribution of root-knot nematodes in the area and nematode preference was influenced by environmental factors regarding the availability of the host. The nematode in the presence of more than one host prefers cucurbits especially cucumber and okra among vegetables grown in the area. Tomato producing sites found infested on seven out of 45 observed sites with 15.6 percent incidence. The pathogenic trend of RKN fauna found typical in the area where it found less virulent on worldwide most preferred hosts like tomato and cucumber. It can be predicted that the nematodes virulence was either silenced by the host or there was the presence of some association of microflora with root rhizosphere which makes the nematode infection difficult (Table 1; 2; 3). Beans were found infested on seven locations among 19 observed sites and their incidence was computed as 36.8 percent, whereas eggplants were found infested at 4 sites with 66.7 percent incidence (Table 1). Details trend of natural distribution presented in the map (Figure 1).

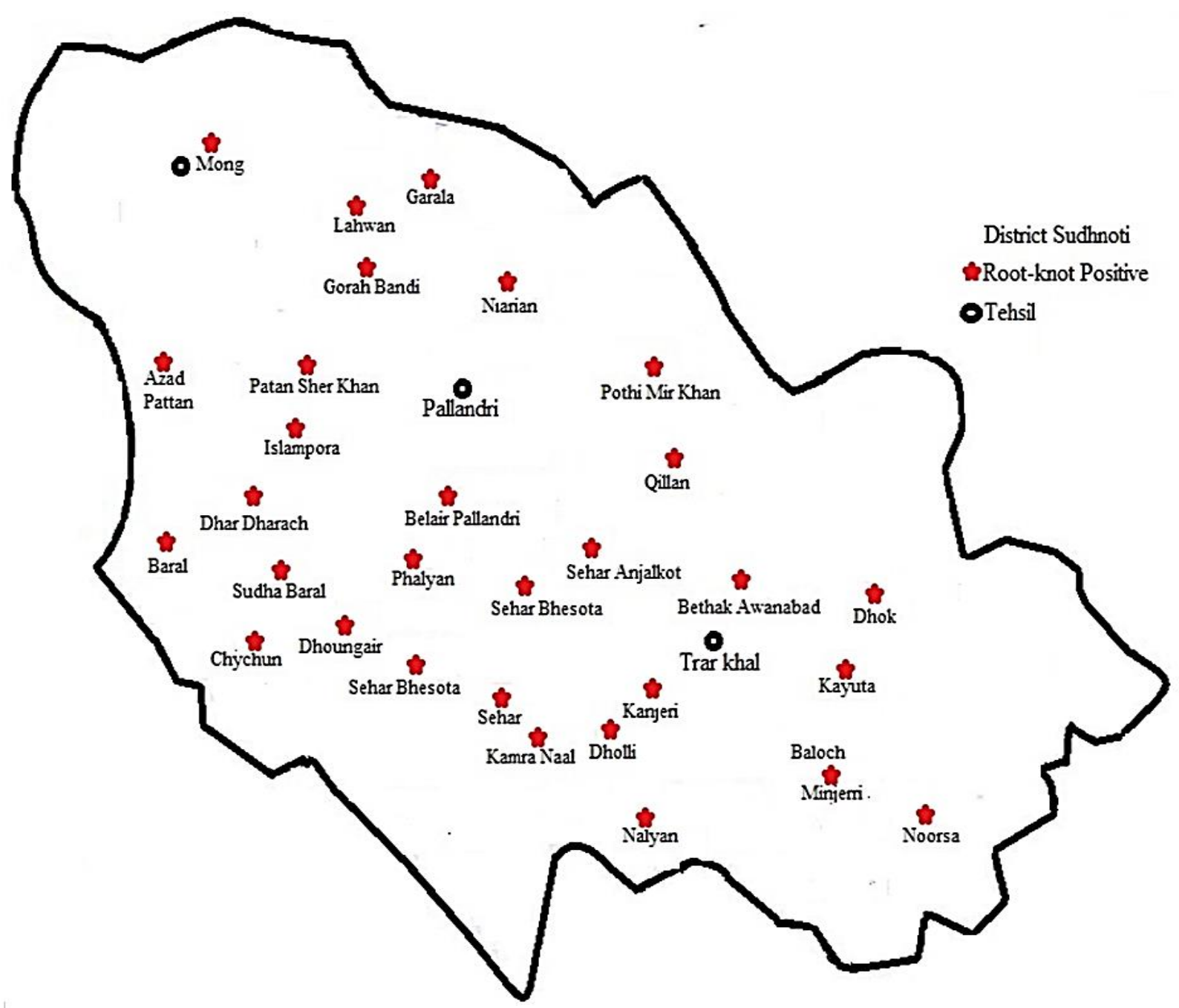

Figure 1: Distribution map of root-knot nematodes from district Sudhnuti of Azad Jammu and Kashmir. 
Table 1: Incidence of root-knot nematodes (RKN) on vegetables from district Sudhnoti Azad Jammu and Kashmir.

\begin{tabular}{lccc}
\hline Crops & Observed fields & Fields RKN +tive & Incidence \\
\hline Cucurbits & 46 & 09 & $19.6 \%$ \\
Tomato & 45 & 07 & $15.6 \%$ \\
Cucumber & 29 & 11 & $37.9 \%$ \\
Okra & 23 & 09 & $39.1 \%$ \\
Beans & 19 & 07 & $36.8 \%$ \\
Eggplant & 06 & 04 & $66.7 \%$ \\
Total & 65 & 47 & $72.3 \%$ \\
\hline
\end{tabular}

Table 2: Details of the root-knot nematode survey from District Sudhnuti, Azad Jammu and Kashmir.

\begin{tabular}{|c|c|c|c|c|c|c|c|c|}
\hline S. No. & Sampling Sites & RKN & Host Crops & $M i$ & $M j$ & $M a$ & $\mathrm{GI}$ & Vegetables found as non-hosts \\
\hline 1 & Belair Pallandri & + & Cucumber & + & + & - & 5 & Chilies, Tomato, Bottle Gourd \\
\hline 2 & Bheta Pallandri & - & --- & - & - & - & --- & Tomato, Bitter Gourd, Chilies \\
\hline 3 & Phalyan & - & --- & - & - & - & --- & Tomato, Okra, Chilies, Mustard leaves \\
\hline 4 & Islampora & + & Tomato & + & - & + & 3 & Chilies, Cucumber \\
\hline 5 & Prat & + & Tomato & - & + & - & 4 & Cucumber, Chilies \\
\hline 6 & Prat Islampora & + & Okra & + & + & + & 2 & Chilies, Bottle Gourd \\
\hline 7 & Dhok & + & Cucumber & + & - & - & 3 & Tomato, Okra \\
\hline 8 & Dhar Dharach & + & Tomato & + & - & - & 3 & Chilies, Cucumber \\
\hline 9 & Baral & + & Bitter Gourd & + & - & - & 7 & Chilies \\
\hline 10 & Sudha Baral & + & Okra & + & + & + & 4 & Chilies \\
\hline 11 & Sudha Baral & + & Cucumber & - & + & - & 2 & Chilies, Fresh Bean \\
\hline 12 & Ori Baral & + & Fresh Bean & - & - & + & 5 & Chilies, Tomato, Okra \\
\hline 13 & Khajori Baral & + & Cucumber & - & + & - & 8 & Okra, Chilies, Tomato \\
\hline 14 & $\begin{array}{l}\text { Dhungair } \\
\text { Chychun }\end{array}$ & + & Tomato & - & + & - & 6 & Chilies, Bottle Gourd, Okra, Cucumber \\
\hline 15 & $\begin{array}{l}\text { Dhungair } \\
\text { Chychun }\end{array}$ & + & Fresh Bean & + & - & - & 5 & Chilies, Bottle Gourd, Okra, Cucumber \\
\hline 16 & $\begin{array}{l}\text { Barwala } \\
\text { Chychun }\end{array}$ & - & -- & - & - & - & -- & Okra, Tomato, Cucumber, Bottle Gourd \\
\hline 17 & Sehar & + & Ridge Gourd & - & + & - & 4 & Cucumber, Bottle Gourd, Chilies \\
\hline 18 & Sehar Anjalkot & + & Okra & + & + & - & 3 & Chilies, Cucumber \\
\hline 19 & Sehar Bhesota & + & Bitter Gourd & - & + & - & 5 & Cucumber, Chilies, Tomato \\
\hline 20 & Goharr Gali & + & Cucumber & + & + & - & 6 & Fresh Bean, Chilies, Tomato \\
\hline 21 & Goharr Gali & + & Ridge Gourd & - & - & + & 3 & Chilies, Fresh Bean \\
\hline 22 & Nalyan & + & Bitter Gourd & + & - & - & 2 & Chilies, Tomato \\
\hline 23 & Nalyan & + & Cucumber & + & - & - & 3 & Bottle Gourd, Tomato \\
\hline 24 & Tahli Nalyan & - & --- & - & - & - & --- & Tomato, Chilies, Bitter Gourd \\
\hline 25 & Tahli Nalyan & + & Fresh Bean & + & - & - & 3 & Chilies, Okra \\
\hline 26 & Tahli Nalyan & + & $\begin{array}{l}\text { Bottle } \\
\text { Gourd }\end{array}$ & - & + & - & 5 & Okra, Chilies \\
\hline 27 & Dholli & + & Tomato & + & + & - & 4 & Chilies, Bottle Gourd \\
\hline 28 & Dholli & + & Bitter Gourd & + & + & - & 2 & Bottle Gourd, Chilies \\
\hline 29 & Kamra Naal & + & Fresh Bean & - & + & - & 3 & Butternut squash, Chilies, Tomato \\
\hline 30 & Kamra Naal & + & Fresh Bean & - & + & - & 4 & Chilies, Tomato, Butternut squash \\
\hline 31 & Kanjerri & + & Okra & + & - & + & 3 & Bottle Gourd, Butternut squash \\
\hline
\end{tabular}




\begin{tabular}{|c|c|c|c|c|c|c|c|c|}
\hline 32 & Kanjerri & + & Okra & - & - & + & 2 & Bottle Gourd, Butternut squash \\
\hline 33 & Gorah Bandi & - & --- & - & - & - & --- & Okra, Tomato, Chilies \\
\hline 34 & Garala & + & Eggplant & + & - & + & 2 & Okra, Bottle Gourd, Fresh Bean, Chilies \\
\hline 35 & Lahwan & + & Okra & + & - & - & 5 & Eggplant, Chilies \\
\hline 36 & Lahwan & + & Okra & - & + & - & 6 & Chilies, Eggplant \\
\hline 37 & Mangriot & - & --- & - & - & - & --- & Chilies, Cucumber, Tomato \\
\hline 38 & Pappynar & + & Cucumber & - & + & + & 3 & Tomato, Okra, Bitter Gourd \\
\hline 39 & Pappynar & + & Okra & + & + & - & 4 & Tomato, Fresh Bean, Cucumber \\
\hline 40 & Kayuta & - & --- & - & - & - & --- & $\begin{array}{l}\text { Tomato, Fresh Bean, Cucumber, Bottle } \\
\text { Gourd }\end{array}$ \\
\hline 41 & Tangi Gala & - & --- & - & - & - & --- & Tomato, Chilies, Fresh Bean \\
\hline 42 & Tangi Gala & - & --- & - & - & - & --- & $\begin{array}{l}\text { Chilies, Cucumber, Butternut squash, } \\
\text { Tomato }\end{array}$ \\
\hline 43 & Trarkhal & - & --- & - & - & - & --- & Tomato, Chilies, Okra, Fresh Bean \\
\hline 44 & Narian & + & Tomato & + & - & - & 6 & Cucumber, Fresh Bean, Chilies \\
\hline 45 & Danna Narian & - & --- & - & - & - & --- & Cucumber, Chilies, Tomato, Fresh Bean \\
\hline 46 & Pothi Mir Khan & + & Fresh Bean & + & + & - & 3 & Chilies, Tomato \\
\hline 47 & Pothi Mir Khan & - & --- & - & - & - & --- & Tomato, Fresh Bean, Bottle Gourd \\
\hline 48 & Qillan & + & Eggplant & - & + & - & 2 & Chilies, Tomato, Bitter Gourd \\
\hline 49 & Qillan & + & Cucumber & - & + & - & 2 & Chilies, Butternut squash, Tomato \\
\hline 50 & Lower Qillan & + & Cucumber & - & - & + & 6 & Butternut squash, Chilies \\
\hline 51 & Lower Qillan & + & Fresh Bean & + & - & - & 7 & Butternut squash, Chilies \\
\hline 52 & Bun Bethal & - & --- & - & - & - & --- & Chilies, Tomato, Butternut squash \\
\hline 53 & Tital Bari & - & --- & - & - & - & --- & Tomato, Cucumber, Butternut squash \\
\hline 54 & $\begin{array}{l}\text { Bethak } \\
\text { Awanabad }\end{array}$ & + & Eggplant & + & - & + & 3 & Chilies, Tomato, Bitter Gourd \\
\hline 55 & Baloch & - & --- & - & - & - & --- & $\begin{array}{l}\text { Tomato, Cucumber, Chilies, Bitter } \\
\text { Gourd }\end{array}$ \\
\hline 56 & Berri Baloch & - & --- & - & - & - & --- & Tomato, Cucumber, Fresh Bean \\
\hline 57 & Noorsa & + & Cucumber & - & - & + & 6 & Okra, Bitter Gourd \\
\hline 58 & Minjarri & + & Cucumber & - & - & + & 6 & Tomato, Chilies \\
\hline 59 & Minjarri Baloch & + & $\begin{array}{l}\text { Butternut } \\
\text { squash }\end{array}$ & - & - & + & 6 & Tomato, Chilies, Bitter Gourd \\
\hline 60 & Minjarri Baloch & + & Eggplant & - & - & + & 5 & Chilies, Bitter Gourd \\
\hline 61 & Azad Pattan & + & Okra & + & - & - & 3 & Tomato, Chilies, Bitter Gourd \\
\hline 62 & $\begin{array}{l}\text { Patan Sher } \\
\text { Khan }\end{array}$ & + & $\begin{array}{l}\text { Butternut } \\
\text { squash }\end{array}$ & - & + & + & 3 & Chilies, Tomato \\
\hline 63 & $\begin{array}{l}\text { Patan Sher } \\
\text { Khan }\end{array}$ & + & Tomato & - & $T$ & + & 4 & Tomato, Chilies \\
\hline 64 & Mang & - & - & - & - & - & - & Tomato, Bitter Gourd, Cucumber \\
\hline 65 & $\begin{array}{l}\text { Naka Bazar } \\
\text { Mong }\end{array}$ & - & - & - & - & - & - & Okra, Bottle Gourd, Butternut squash \\
\hline
\end{tabular}

Mi; Meloidogyne incognita; Ma: M. arenaria; Mj: M.javanica; GI: Galling index

Severity of root-knot disease on vegetable crops form district Sudhnuti: Our field survey of the study area based on visual observation of the field symptoms and visual scoring by comparison with the described standards (Bridge and Page, 1980) of RKN disease severity virulence scale revealed the pathogenicity trend in the Sudhnuti. Data shows that most of the areas where the temperature is low around the year have low disease 
severity (2-3) as compared to comparatively warmer areas, which are favoring the root-knot nematode population buildup. Scoring shows that $45 \%$ of sites are having RKN but not a substantial risk to the crop yield. Continuous monitoring is required to keep the nematode population below the threshold level. Disease scoring in the range of four is considered as sensitive sites for the presence of RKN fauna to keep management practices active. A total of $13 \%$ surveyed sites fell in this category, which needs not only monitoring but management as well. Eighteen sites are found with disease severity, which is harmful to the crop yield, which is $38 \%$ of the surveyed sites. However, in some places, the disease severity is high on 16 locations, which is $5-7$ on the disease severity index (Table 2; 3). Any negligence regarding root-knot nematodes management can lead to a future threat to the surveyed field production.

Species Composition in the surveyed areas: Identification of root-knot nematode species based on the perineal pattern morphology revealed the special profile of various species of RKN present in the district targeting a variety of vegetables in single and as combinations. Tropical nematode species Meloidogyne incognita (Mi), Meloidogyne javanica (Mj), and Meloidogyne arenaria (Ma) were found parasitizing vegetables in the study area. On 11,12, and 8 sampling sites $M$. incognita, M. javanica and M. arenaria were found as alone species respectively, while on 2 sampling sites all 3 species were found concomitantly, $(M i+M j)$ on 6. $(M i+M a)$ on 4 and $(M j+M a)$ on 3 sites. Some preferences for host selection were found by different species of root-knot nematodes (Table 3).

Table 3: Severity range of root-knot nematode disease on vegetables in District Sudhnuti, Azad Jammu and Kashmir.

\begin{tabular}{lccccc}
\hline Crops & locations & RKN+ & Severity Range & Average severity & Galling Index (GI) \\
\hline Eggplant & 06 & 04 & $2-5$ & $3.0 \pm 1.414$ & 6 \\
Tomato & 45 & 07 & $3-6$ & $4.3 \pm 1.253$ & 5 \\
Cucumber & 29 & 11 & $2-8$ & $4.5 \pm 2.018$ & 1 \\
Okra & 23 & 09 & $2-6$ & $3.5 \pm 1.333$ & 2 \\
Beans & 19 & 07 & $3-7$ & $4.3 \pm 1.496$ & 4 \\
Cucurbits & 46 & 09 & $2-7$ & $4.1 \pm 1.763$ & 3 \\
\hline
\end{tabular}

\section{DISCUSSION}

Root-knot nematodes (RKN) are the most important genus of plant-parasitic nematodes with worldwide distribution (Bhosle et al., 2004; Ravichandra and Krishnappa, 2004; Rathour et al., 2006). The current study was carried out in Sudhnoti district of Azad Jammu and Kashmir having temperate to sub-temperate climatic conditions with snowfall on high mountains and foothills. Distribution trends of RKN distribution vary among countries and within countries due to geographical and climatic variations (Khan et al., 2005, Shahid et al., 2007). In our study area, RKN distribution was more prevalent in foothill areas below 5000 feet from sea level. Among 65 visited sites for incidence, occurrence, and distribution of RKN, 47 sites were found infested. Major crops found parasitized were eggplant, tomato, cucumber, okra, beans, and cucurbits. The total incidence of vegetable crops was 72.30 percent. The cucumber was highly infested at 11 locations with galling index (GI) range 2-8, okra at 9 locations with 2-6, tomato at 7 locations with 3-6, eggplant at locations 4 with 2-5 while cucurbits and beans at 9 and 7 locations with galling indices 2-7 and 3-7 respectively. Non-host crops found during the survey are chilies, maize, garlic, onion, and potatoes; although the conditions for RKN were favorable for infestation natural resistance of these crops against RKN and use of hybrid varieties play a vital role in preventing RKN establishment. Previous studies on the distribution of the root-knot nematode were limited on okra and tomato and incidence was $64 \%$ and galling index range was 3-8 on Bridge and Page scale (1980) and distributed species were M. incognita, $M$. javanica and $M$. arenaria as mix populations which are somehow similar in the previous studies of the area (Tariq-Khan et al., 2017; Tariq Khan, 2018; Tariq-Khan et al., 2020). The highest incidence and severity of RKN were due to suitable hosts, soil texture, $\mathrm{pH}$, and moisture.

Tropical RKN species Meloidogyne javanica, M. incognita, and $M$. arenaria area frequently found distributed in the study area, in the mixture and sole population. Which is differing from the previous distribution studies in Poonch division of AJK (Tariq-Khan et al., 2020). M. javanica and $M$. incognita were found as predominant 
species distributed widely in various localities of the district Sudhnuti. Unlike other temperate regions of the world, we could not find any evidence of the M. hapla in this study area which is the same trend as previously reported (Tariq-Khan et al., 2017). Tropical RKN species were already reported at a high altitude of Pothohar region and Azad Jammu and Kashmir (Kayani et al., 2013; Khan, 2018). Soil pH, high rainfall, sandy and clayey soil of the area favored these species for their development and aggressiveness. Previously, about 47 percent distribution of Meloidogyne species on vegetables was reported globally, 52 percent in the soils of Pakistan, and 85 percent was reported from Punjab (Anwar et al., 2007a; Anwar et al., 2007b). The distribution map (Figure 1) will be helpful in the future mapping of RKN population and distribution pattern. The study enriched and added the existing knowledge of RKN distribution in the study area and its pathogenic trends among cultivated vegetables. Furthermore, some finding influence the scientist to know deep into the mechanism of resistance in tomato and other cucurbits for a low level of infection. Might be there is some mycorrhizal relationship among the soil microbial community which naturally silencing the virulence genes in the root-knot nematodes making plant resistant. These results will be helpful in designing environmentally friendly and effective management strategies against root-knot nematodes for district Sudhnoti of Azad Jammu and Kashmir, Pakistan.

\section{Authors Contributions:}

MTK, MI and ADAK designed the study; ADAK and ZAG executed the survey and collected the data. MTK, ADAK, and ZAG analyzed the data and wrote the manuscript while RA and MS edited and standardized the manuscript. All the authors approved the final manuscript.

Conflict of Interest: The authors declare no conflict of interest.

\section{REFERENCE}

Anwar, S. A., A. Z. Hussain and M. Kamran. 2007. Host suitability of selected plants to Meloidogyne incognita in the Punjab Pakistan. International Journal of Nematology, 17: 144-50.

Anwar, S. A. and M. V. Mckenry. 2012. Incidence and population density of plant parasitic nematodes infecting vegetable crops and associated yield losses in Punjab, Pakistan. Pakistan Journal of Zoology, 44: 327-37.
Anwar, S. A., A. Zia, M. Hussain and M. Kamran. 2007b. Host suitability of selected plants to Meloidogyne incognita in the Punjab, Pakistan. International Journal of Nematology, 17: 144-50.

Barker, K. R., G. A. Pederson and G. L. Windham. 1998. Plant and nematode interactions; Agronomy Monograph American society of Agronomy, Mdison. WI.

Benson, D. M. and K. R. Barker. 1985. Nematodes-A threat to ornamental plants in the nursery and landscape Plant Disease, 69: 92-100.

Bhosle, B. B., S. Mukesh, S. N. Puri and D. Suvasish. 2004. Prevalence of phytophagous nematodes in rhizosphere of okra (Abelmoschus esculentus (L.) Moench.) in Parbhani District, Maharashtra, India. Indian Journal of Nematology, 34: 56-59.

Bridge, J., and S. L. J. Page. 1980. Estimation of root-knot nematode infestation levels on roots using a rating chart. Tropical Pest Management, 26: 296-98.

Bridge, J. and S. L. J. Page. 1980. Estimation of root-knot nematode infestation levels on roots using a rating chart. Tropical Pest Management, 26: 296-98.

Hussey, R. S. and G. J. W. Janssen. 2002. Root-knot Nematodes Meloidogyne Species. In: J. L. Starr, R. Cook and Bridge. J. (eds.), Plant resistance to parasitic nematodes CABI: New York.

Kayani, M. Z., T. Mukhtar, M. A. Hussain and M. I. UlHaque. 2013. Infestation assessment of root-knot nematodes (Meloidogyne spp.) associated with cucumber in the Pothowar region of Pakistan. Crop Protection, 47: 49-54.

Khan, H. U., T. Mukhtar and R. Ahmed. 2005. Geographical distribution of RKN in Punjab Province of Pakistan. . Pakistan Journal of Nematology, 23: 133-40.

Khan, M. T. 2018. Genetic Characterization of root-knot nematodes (Meloidogyne spp.) from vegetable crops of Azad Jammu and Kashmir, The University of Agriculture Peshawar Pakistan.

Maqbool, M. A. and F. Shahina. 2001. Systematic and distributions; biodiversity of nematode fauna in Pakistan Karachi University: National Nematological Research Centre, University of Karachi, Pakistan.

Rathour, K. S., P. Jola and G. Sudershan. 2006. Community structure of plant parasitic nematodes in Champawat District of Uttaranchal, India. Indian Journal of Nematology, 36: 89-93. 
Ravichandra, N. G. and K. Krishnappa. 2004. Prevalence and distribution of phytoparasitic nematodes associated with major vegetables crops in Mandya District, Karnataka. Indian Journal of Nematology, 34: 113-16.

Shahid, M., A. U. Rehman, A. U. Khan and A. Mahmood. 2007. Geographical distribution and infestation of plant parasitic nematodes on vegetables and fruits in the Punjab Province of Pakistan. Pakistan Journal of Nematology, 25: 59-67.

Sikora, R. A. and E. Fernández. 2005. Nematode parasites of vegetables. In: M. Luc, R. A. Sikora and J Bridge (eds.), Plant parasitic nematodes in subtropical and tropical agriculture, 2nd edition CABI Publishing, : Wallingford UK.

Tariq-Khan, M., T. Mukhtar, A. Munir, H. Hallmann and H. Heuer. 2017. Distribution of root-knot nematode species and their virulence on vegetables in northern temperate agro-ecosystems of the Pakistani-administered territories of Azad Jammu and Kashmir. Journal of Plant Diseases and Protection, 124: 201-12.

Tariq-Khan, M., T. Mukhtar, A. Munir, H. Hallmann and H. Heuer. 2020. Comprehensive report on the prevalence of root-knot nematodes in the Poonch division of Azad Jammu and Kashmir, Pakistan. Journal of phytopathology, 168: 322-36.

Tariq Khan, M. 2018. Genetic Characterization Of RootKnot Nematodes (Meloidogyne Spp.) From Vegetable Crops of Azad Jammu And Kashmir, Dissertation, The University of Agriculture, Peshawar.

Wesemael, W. M. L., N. Viaene and M. Moens. 2011. Rootknot nematodes (Meloidogyne spp.) in Europe. Nematology, 13: 3-16.

\section{Contribution of Authors:}

All authors contributed equally in the research work and writing this manuscript. 